\title{
Use of Force against Non-State Actors and the Circumstance Precluding Wrongfulness of Self-Defence
}

\author{
by Federica I Paddeu* \\ Contemporary private terrorism constitutes a new kind of threat. \\ It demands new kinds of thinking. ${ }^{1}$
}

\section{Abstract.}

The right of self-defence against non-State actors is increasingly invoked and accepted in the practice of States. However, the recognition of this right must overcome a fundamental obstacle: that of explaining why the rights of the host State, in particular its right of territorial sovereignty, is not infringed by the self-defensive force used within its territory. In practice, States invoking self-defence against non-State actors rely on the involvement of the host State with those actors to justify the use of force in that State's territory. It is not clear, from a legal standpoint, how to rationalize the fact of involvement as a form of legal justification. For some, involvement amounts to attribution. For others, involvement is a form of complicity. For others still, involvement may entail a breach of the host State's due diligence obligation to protect the rights of other States in its territory. All of these solutions are deficient in some way, and have failed to receive generalized endorsement. This article considers whether there may be a different, as yet neglected, solution: self-defence as a circumstance precluding wrongfulness. The article shows that this is not a perfect solution either, since positive law remains uncertain on this point. Nevertheless, it is a solution that may provide a better normative framework for the development of the law of self-defence against nonState actors.

Key words. Self-defence, non-State actors, use of force, circumstances precluding wrongfulness, armed attack

\footnotetext{
Abogado (UCAB, Caracas), LLM, PhD (Cantab). Junior Research Fellow and John Tiley Fellow in Law at Queens' College, Cambridge; Fellow of the Lauterpacht Centre for International Law, Cambridge.

1 T. Becker, Terrorism and the State. Rethinking the Rules of State Responsibility (2006), at 1.
} 


\section{Introduction}

The use of force by non-State actors is an unfortunate but recurring phenomenon in international affairs. It is, to be sure, not a new phenomenon. One of the most famous episodes in the history of international law, the Caroline incident between the US and Great Britain in 1837, involved the use of cross-border force by insurgents. ${ }^{2}$ In contemporary conditions, the threat posed by non-State actors' uses of force is, however, greater than it has ever been. Technological and military advancements, as well as their availability to private actors, has exponentially increased non-State actors' capacity for destruction. ${ }^{3}$ It is only necessary to read the daily news to realize just how devastating the actions of these irregular groups can be. How to deal with this phenomenon (in all its aspects) is one of the most pressing issues in, and most important challenges for, contemporary international law.

One of the central questions in this regard is that of the availability of a right of self-defence against non-State actors on the part of States that are victims of military attacks by these groups. ${ }^{4}$ Since 1945 at least, international law has envisaged a right of self-defence applicable in inter-State relations only: by a victim State against the aggressor State. ${ }^{5}$ In this framework, uses of force by armed bands and the like, to trigger the right of self-defence, had to be attributed to a State which would then become the author of the attack and the target of self-defensive force. ${ }^{6}$ But since the attacks on the World Trade Center on 9/11, States have increasingly called into question this understanding of the right of self-defence by invoking the right to respond to non-State actors' uses of force. $^{7}$ To cite two well-known examples, it was widely recognized that the US acted in self-defence against Al-Qaida in 2001, ${ }^{8}$ and Iraq and its allies, including France, the UK and the US, have asserted a right of self-defence (be it individual or collective) against

\footnotetext{
2 On which see, generally, R. Jennings, 'The Caroline and McLeod Cases', (1938) 32 AJIL 82.

T. Ruys, 'Armed Attack' and Article 51 of the UN Charter (2010), at 488. 4 The discussion assumes that non-State actors operate in a cross-border fashion, from the territory
of a different State. States are not prohibited by international law to use force within their own borders to tackle these threats, within limits imposed by human rights law and, if and to the extent applicable, humanitarian law.

5 See, eg, Legal Consequences of the Construction of a Wall in the Occupied Palestinian Territory, Advisory Opinion of 9 July 2004, [2004] ICJ Rep. 136, at 194, para. 139.

6 As asserted by the International Court of Justice in Military and Paramilitary Activities in and Against Nicaragua (Nicaragua v United States of America), Merits Judgment of 27 June 1986, [1986] ICJ Rep. 14, at 103, para. 195.

$7 \quad$ For a review of practice, see: Ruys, Armed Attack, at 447-472; R. van Steenberghe, La légitime défense en droit international public (2012), at 292-325; O. Corten, Le droit contre la guerre (2nd edn, 2014), at 74353.

$8 \quad$ UNSC Res. 1368 (2001). The literature on the US's exercise of self-defence in Afghanistan is vast. For a review of the facts and the main scholarly approaches, see: Becker, Terrorism and the State, ch 6.
} 
ISIS in Syria. ${ }^{9}$ Whether this practice is sufficient (and sufficiently uniform) ${ }^{10}$ to evidence a change in the traditional understanding of self-defence is still a contentious issue. ${ }^{11}$ The most charitable view in this regard is that the use of force in self-defence against nonState actors is not 'not unambiguously illegal'; ; but even then, it is unclear that this view is generally accepted.

In no small part, the difficulty with recognizing a right of self-defence against non-State actors is that of explaining why the State in whose territory those actors operate (the 'host State') is liable to the use of force within its territory. The 'dilemma', as Tom Ruys and Sten Verhoeven put it, is 'clear':

On the one hand, it can not be accepted that states must simply undergo private attacks without having the right to defend themselves by using force against the home bases of these groups and their accomplices [...] On the other hand, state sovereignty is and remains one of the basic pillars of international law and order and should not lightly be violated. ${ }^{13}$

Why must the host State tolerate the infringement of its territorial sovereignty, or a (forcible) intervention in its affairs, or the impairment of, say, legally protected trade and other commercial relations, by the victim's use of force? In considering this question, Kimberley Trapp has (rightly) observed that self-defence must 'in some way excuse the

9 See summary record of the SC meeting of 20 November 2015, S/PV.7565, at 2 (France), 4 (US), 9 (UK). See also the following letters to the Security Council: UN Docs. S/2014/695 (US); S/2014/851 (UK); S/2015/745 (France). For scholarly analyses of the situation in Syria, see: L. Arimatsu and M.N. Schmitt, 'Attacking "Islamic State" and the Khorasan Group: Surveying the International Law Landscape', (2014) 53 Colum I Transnat'l L Bulletin 1; M. Hakimi, 'Defensive Force against Non-State Actors: The State of Play', (2015) 91 Int'l Legal Studies 1. The matter has also been addressed in numerous blog posts, e.g.: J.D. Ohlin, 'The Unwilling or Unable Doctrine Comes to Life', Opinio Juris, 23 September 2014, < http://opiniojuris.org/2014/09/23/unwilling-unable-doctrine-comes-life/>; M. Hakimi, 'Assessing (Again) the Defensive Operations in Syria', Just Security, 22 January 2015, <https://www.justsecurity.org/19313/assessing-again-defensive-operations-syria/>; C. Kreß, 'The Fine Line Between Collective Self-Defense and Intervention by Invitation: Reflections on the Use of Force against "IS" in Syria', Just Security, 17 February 2015, <https://www.justsecurity.org/20118/claus-krebforce-isil-syria/>; R. van Steenberghe, 'From Passive Consent to Self-Defence after the Syrian Protest against the US-led Coalition', EJIL:Talk!, 23 October 2015, <http://www.ejiltalk.org/13758-2/>.

10 There are some methodological debates as to whether the practice should prove a modification of the rule or the existence of a new rule, on which see: O. Corten, Droit contre la guerre, at 35-63; R. van Steenberghe, 'State Practice and the Evolution of the Law of Self-Defence: Clarifying the Methodological Debate', (2015) 2 JUFIL 81.

$11 \quad$ Ruys, Armed Attack, at 487-9, 531.

12 Ruys, Armed Attack, at 531. The expression is taken from a paper of the UK Foreign and Commonwealth Office, titled 'Is intervention ever justified', Foreign Policy Document no 148, 1986, reprinted in 'UK Materials in International Law', (1986) 57 BYIL 614. For a similar position, see: C. Antonopoulos, 'Force by Armed Groups as Armed Attack and the Broadening of Self-Defence', (2008) 55 NILR 159.

13 T. Ruys and S. Verhoeven, 'Attacks by Private Actors and the Right of Self-Defence', (2005) $10 \mathrm{~J}$ Conflict \& Security Law 289 at 310. 
violation of these rights of the host State if it is to be an effective mechanism. ${ }^{14}$ It may be added that the legal justification of the impairment of host State rights is necessary to avoid triggering the host State's right of self-defence against the victim State; to uphold, in short, the principle that there is no self-defence against self-defence. ${ }^{15}$ Indeed, if the victim's use of force is, from the standpoint of the host State, a forcible violation of its sovereignty, then why can the host State not react in self-defence against it ${ }^{16}$ Farfetched as this may sound, a right of self-defence in these circumstances was invoked by Syria in the wake of indications by the US and other European powers that they intended to attack ISIS targets within Syria's territory as an exercise of collective self-defence of Iraq. ${ }^{17}$

There are many disagreements as to the conditions and the legal ground of justification for the impairment of host State's rights by self-defensive action-if one exists at all. At a bare minimum, States and scholars agree that any such justification must be grounded, in some measure, on the involvement of the host State with the non-State actors mounting the attack. This is evidenced by the references to, for example, the 'harbouring' by Afghanistan of Al-Qaida ${ }^{18}$ and, most recently, by the claim of Iraq and the US that Syria was unwilling or unable to deal with ISIS in its territory. ${ }^{19}$ To be sure, host State involvement with the non-State actors warrants differential treatment

14 K. Trapp, 'The Use of Force against Terrorists: A Reply to Christian J Tams', (2009) 20 EJIL 1049 at 1050.

15 United States v von Weizsaecker et al (Ministries trial) (1949) 14 NMT 314, at 329. For an earlier statement of this principle, see: The Maria (1799) 1 C Rob 340, at 361 ('it is a wild conceit, that wherever force is used, it may be lawfully resisted. A lawful force cannot be lawfully resisted'). See also, N. Lubell, Extraterritorial Use of Force Against Non-State Actors (2010), at 41; Y. Dinstein, War, Aggression and Self-Defence (5th edn, 2012), at 190.

16 For this reason, the encroachment upon the host State's rights must be justified (namely, rendered lawful) and not just excused. Excuse defences exclude the consequences of unlawfulness (eg, cessation and reparation), without having an effect on the illegality of the relevant conduct. If the infringement of host State rights were merely 'excused', this would mean that the victim State may not owe reparations to the host State, but it would not be enough to prevent the host State's right of self-defence from being triggered: the use of force in its territory would remain unlawful and, if it reaches the required gravity, it could constitute an armed attack. On the distinction between justification and excuse in international law, see: V. Lowe, 'Precluding Wrongfulness or Responsibility: A Plea for Excuses?', (1999) 10 EJIL 405; T. Christakis, 'Les “circonstances excluant l'illicéité”: une illusion optique?', in O. Corten et al (eds.), Droit du pouvoir, pouvoir du droit: Mélanges offerts à Jean Salmon (2007), 223; G. Scalese, La rilevanza delle scusanti nella teoria dell'illecito internazionale (2008); F. Paddeu, General Defences in International Law: Justification and Excuse in the Law of State Responsibility (2013), at ch 3, Unpublished Doctoral Dissertation, University of Cambridge.

17 See T. Ruys and N. Verlinden, 'Digest of State Practice: 1 July-31 December 2014', (2015) 2 JUFIL 119 at 135. According to the Syrian Minister of National Reconciliation Affairs '[a]ny action of any type without the approval of the Syrian government is aggression against Syria', id.

18 See, eg, the letters sent to the UN Security Council by: Canada: UN Doc. S/2001/1005; the European Union: UN Doc. S/2001/967; Germany: UN Doc. S/2001/1127; and New Zealand: UN Doc. S/2001/1193.

19 See the references in note 7 . 
depending on the kind and degree of the relationship between the two. ${ }^{20}$ Where involvement is enough for attribution of the private conduct to the State, self-defence can be exercised in an inter-State manner. ${ }^{21}$ Where attribution is not possible, two questions arise: first, what kind and degree of involvement is necessary and, second, how to rationalize the fact of host State involvement into a ground of legal justification. As to the kind and degree of involvement, agreement seems to be coalescing around a standard of 'unwillingness and inability' of the host State to deal with the non-State actors. ${ }^{22}$ But host State involvement is a factual question, ${ }^{23}$ and does not, on its own, constitute a legal ground of justification. It is thus necessary to rationalize this fact into one such legal ground. The latter point is still controversial; many solutions have been proposed in the literature, but none of these has received general endorsement. ${ }^{24}$

The majority of the debates on self-defence against non-State actors have centred on Article 51 of the Charter, ${ }^{25}$ either to demonstrate that the restrictive inter-State understanding is not supported by the language of the provision or intended by the drafters, ${ }^{26}$ or to identify a different standard of attribution of the non-State actors' attack to the host State. ${ }^{27}$ These works constitute a crucial step for the development of the law of self-defence, if this body of law is to adequately address the threat posed by non-State actors. Nevertheless, this focus has also produced the 'dilemma' that Ruys and Verhoeven mention: Article 51 (may) authorize the use of force against the non-State

20 For an example of this differential treatment, see: A. Becker Lorca, 'Rules for the "Global War on Terror”: Implying Consent and Presuming Conditions for Intervention’, (2012) 45 NYU Journal of Int'l Law and Politics 1.

21 Even in this case, the interference with the target State's rights of territorial sovereignty and nonintervention, among others, require legal justification, as will be explained in Section 2.

22 On which see, generally, A. Deeks, "Unwilling or Unable": Toward a Normative Framework for Extraterritorial Self-Defense', (2012) 52 Va J Int'l L 483. See also: T. Reinold, 'State Weakness, Irregular Warfare, and the Right of Self-Defense Post-9/11', (2011) 105 AJIL 244.

23 T. Ruys, 'Crossing the Thin Blue Line: An Inquity into Israel's Recourse to Self-Defense Against Hezbollah', (2007) 43 Stan J Int'l L 265, 283 (noting that State involvement with non-State actors 'is not easy to assess [and] ultimately boils down to a factual and contextual assessment').

$24 \quad$ See infra Section 3.2.2.

$25 \quad$ Pursuant to art 51: 'Nothing in the present Charter shall impair the inherent right of individual or collective self-defence if an armed attack occurs against a Member of the United Nations, until the Security Council has taken measures necessary to maintain international peace and security. Measures taken by Members in the exercise of this right of self-defence shall be immediately reported to the Security Council and shall not in any way affect the authority and responsibility of the Security Council under the present Charter to take at any time such action as it deems necessary in order to maintain or restore international peace and security', 1945 Charter of the United Nations, 1 UNTS 16.

26 See, eg, S. Murphy, "Terrorism and the Concept of "Armed Attack" in Article 51 of the UN Charter', (2002) 43 Harv ILJ 42; R. van Steenberghe, 'Self-Defence in Response to Attacks by Non-State Actors in the Light of Recent Practice: A Step Forward?', (2010) 23 LJIL 183; S. Ratner, 'Self-Defence Against Terrorists: The Meaning of Armed Attack', in L. van den Herik and N. Schrijver (eds.), CounterTerrorism Strategies in a Fragmented International Legal Order - Meeeting the Challenges (2013), 334.

27 van Steenberghe usefully reviews the arguments made under several of the ARS rules on attribution in van Steenberghe, Légitime défense, at 311-23. 
actors, but it fails to address the relations between victim State and host State. In contrast with this approach, this study queries whether Article 21 of the Articles on the Responsibility of States for Internationally Wrongful Acts ('ARS') ${ }^{28}$ may provide an answer to the 'dilemma'. ${ }^{29}$ Pursuant to Article 21:

The wrongfulness of an act of a State is precluded if the act constitutes a lawful measure of self-defence taken in conformity with the Charter of the United Nations.

Curiously, the vast literature on self-defence against non-State actors has thus far overlooked Article 21. In fairness, this provision is mostly neglected in the scholarship on the use of force, ${ }^{30}$ and when actually addressed it has been largely misunderstood. ${ }^{31}$ Can Article 21 provide the legal justification for the impairment of host State rights by self-defensive force used within its territory?

The study answers this question in three parts. First, in Section 2, it will begin by explaining the intended role and scope of Article 21 of the ARS. The section will describe the context and historical developments which rendered this provision necessary, and will show how, even though unacknowledged in practice, self-defence operates to preclude the wrongfulness of the infringement of other rights of the target State by lawful measures of self-defence. Second, in Section 3, the study then considers the possible application of Article 21 in the context of self-defence against non-State actors within the host State. Finally, Section 4 will provide some concluding remarks.

Before entering into the substance of this study, some methodological and terminological observations are necessary. As to the methodology, this study is limited to the theoretical question of how to justify the encroachment of host State rights by the use self-defensive force in its territory. In accordance with the trend in State practice, this

\footnotetext{
28 Articles on the Responsibility of States for Internationally Wrongful Acts (hereinafter ARS and Commentary) Annexed to UN Doc A/RES/56/83 (2002).

29 On this provision see, generally, J.M. Thouvenin, 'Self-Defence', in J. Crawford et al (eds), The Law of International Responsibility (2010), 455; J. Crawford, State Responsibility: The General Part (2013); F. Paddeu, 'Self-Defence as a Circumstance Precluding Wrongfulness: Understanding Article 21 of the Articles on State Responsibility', (2014) 85 BYIL. (forthcoming).

30 As an example, the recent Oxford Handbook on the Use of Force in International Law, edited by Marc Weller, and containing over 50 chapters, does not contain a chapter on Article 21.

31 See, eg, T. Christakis and K. Bannelier, 'La légitime défense en tant que "circonstance excluant l'illicéité", in R. Kherad (ed.), Légitimes défenses (2007) 233; T. Christakis and K. Bannelier, 'La légitime défense a-t-elle sa place dans un code sur la responsabilité internationale?', in A. Constantinides and N. Zaikos (eds.), The Diversity of International Law: Essays in Honour of Professor Kalliopi K Koufa (2009), 519. These authors consider that Article 21 is 'useless' (they use the term 'inutile' in French) insofar as the relations between the victim and aggressor States are concerned.
} 
paper will assume that host State involvement with the non-State actors launching the attack is necessary. In particular, given its recent momentum, this paper will assume that the kind and degree of host State involvement necessary amounts to "unwillingness or inability'. The study will not, therefore, seek to prove or disprove this test by reference to State practice; equally, it will not elaborate on the precise content of the standard. ${ }^{32}$ As to terminology, in order to avoid confusion between the two provisions in Article 51 of the Charter and Article 21 ARS, the rule in Article 51 will be referred throughout as the 'right of self-defence' or the 'primary rule of self-defence', whereas the rule in Article 21 will be referred to as the 'circumstance precluding wrongfulness', 'justification' or 'secondary rule' of self-defence. This use of terminology should not suggest, however, that these are two different norms. As Section 2 will clarify, the customary law recognizes a right of self-defence, and its functions and effects in the international legal order are codified in two provisions: Article 51 excepting self-defence from the prohibition of force, and Article 21 providing a justification for the collateral impairment of rights of the target State by self-defensive force.

\section{Self-defence as a circumstance precluding wrongfulness}

Until 1945 the institution of the state of war (also known as 'formal' or 'technical' war) governed all of the legal relations existing between belligerent States. ${ }^{33}$ The state of war wholly excluded the law of peace, and replaced it with the law of war in the relations between belligerents. ${ }^{34}$ Moreover, (peace-time) treaties were terminated or, at the very least, suspended in the relations between the parties. ${ }^{35}$ As a result, the military measures adopted by either party to the conflict could not infringe or even impair the rights and obligations which governed their relations during peace.

The state of war is now an institution of pure historical interest. Whether it is compatible with the Charter's collective security system remains debatable, ${ }^{36}$ but it is certainly the case that States no longer claim to be in a 'state of war' when they are

\footnotetext{
32 For this, see: Deeks, 'Unwilling or Unable'.

33 The state of war consisted of the situation, condition or status during which the extraordinary law of war substituted the law of peace in the regulation of the relations between the parties to the conflict, see Q. Wright, 'When does War Exist?', (1932) 26 AJIL 362 at 363.

$34 \quad$ S. Neff, War and the Law of Nations (2005), at 177.

See, eg, North Atlantic Coast Fisheries Case (Great Britain/US) (1910) 11 RIAA 167, at 181 ('International law in its modern development recognizes that a great number of Treaty obligations are not annulled by war, but at most suspended by it'). The doubts surrounding this question in the early 20th century were described by C. Hurst, 'The Effect of War on Treaties', (1921) 2 BYIL 37.

$36 \quad$ For a summary of the scholarly debate see Neff, War, at 335-40.
} 
engaged in armed conflict. ${ }^{37}$ In contemporary conditions, States engaged in armed conflict remain "formally at "peace", ${ }^{38}$ which means that all their legal relations remain in force throughout the period of hostilities. ${ }^{39}$ In these conditions, the use of force can impair a multiplicity of obligations existing between the two States engaged in conflict. For example, when the use of force occurs in the target State's territory, that force will constitute a breach of the prohibition of force, and it will also, among others, be an impairment of the target's territorial sovereignty ${ }^{40}$ and of its right to be free from intervention. $^{41}$

Ordinarily, these impairments constitute breaches of international law. But what if a State resorts to force in self-defence? Customary international law recognizes the right of States to use force in self-defence when they are the victims of an armed attack. This is a unanimously accepted entitlement, ${ }^{42}$ codified in Article 51 of the UN Charter and regularly described as an 'exception' to the prohibition of force. ${ }^{43}$ Resort to force in selfdefence, being excepted from the prohibition of force, does not therefore constitute an infringement of that prohibition. That use of force is lawful by reference to the prohibition of force itself. But what about the other legal relations just mentioned, is defensive force lawful also by reference to these legal relations? As will be seen, Article 21 of the ARS is intended to justify the impairment caused by lawful force on these other legal relations.

37 See the exhaustive review of practice in M. Mancini, Stato di guerra e conflitto armato nel diritto internazionale (2009), ch 4. See also, for practice related to commercial and economic relations, S. Silingardi, Gli effetti giuridici della guerra sui rapporti economici e commerciali (2012).

38 ARS art 21 Commentary, at para. 2. See also J. Crawford, Second Report on State Responsibility, UN Doc. A/CN.4/498 and Add.1-4 (1999), at 75, para. 299.

39 Including treaties, at least as a matter of principle. See art 3 of the ILC's Articles on the Effects of Armed Conflict on Treaties, with Commentaries, Report of the ILC on the work of its sixty-third session, UN Doc. A/66/10 (2011).

$40 \quad$ Nicaragua, Memorial of Nicaragua, 30 April 1985, ICJ Pleadings, vol IV, at 115; Border and Transborder Armed Actions (Nicaragua v Honduras), ICJ, Application instituting proceedings, 28 July 1986, at 5 7; Border and Transborder Armed Actions (Nicaragua v Costa Rica), ICJ, Memorial of Nicaragua, 19 August 1987, at 109; Armed Activities on the Territory of the Congo (DRC v Burundi), ICJ, Application instituting proceedings, 23 June 1999, at 15-9; Armed Activities on the Territory of the Congo (DRC $v$ Rwanda), ICJ, Application instituting proceedings, 23 June 1999, at 16-9; Aerial Incident of 10 August 1999 (India v Pakistan), ICJ, Application instituting proceedings, 21 September 1999, at section II; Land and Maritime Boundary between Cameroon and Nigeria (Cameroon v Nigeria: Equatorial Guinea intervening), ICJ, Cameroon statement, CR 2002/7, at 36, para. 7; Legality of the Use of Force (Federal Republic of Yugoslavia v Belgium), Preliminary Objections, Judgment of 15 December 2004, [2004] ICJ Rep. 279, at 283, para. 1; Certain Activities Carried out by Nicaragua in the Border Area (Costa Rica v Nicaragua), ICJ, Application instituting proceedings, 18 November 2010, at 4 .

41 Nicaragua, Memorial of Nicaragua, at 120; Nicaragua $v$ Honduras, Application instituting proceedings, 5-7; Cameroon v Nigeria, CR 2002/7, at 36, para. 7; DRC v Burundi, Application instituting proceedings, at 15-9; DRC v Rwanda, Application instituting proceedings, at 16-19; Certain Activities (Nicaragua $v$ Costa Rica), Memorial of Nicaragua, at $55 \mathrm{ff}$.

42 Nevertheless, ambiguities and differences of opinion remain about the meaning and scope of the various conditions and requirements of the exercise of the right.

43 See, eg, Murphy, 'Concept of “Armed Attack", at 44. 
The next two sections unpack Article 21 in an effort to elucidate its role in the international legal order. The analysis will be performed in two steps. First, the legal relations between the victim and the aggressor State will be considered. For analytical purposes, the legal relations between these two States will be divided into three categories and the interaction between self-defence and each of these categories will be considered. Second, this section will consider the question of third-party rights and whether self-defence can provide a justification for the forcible interference of third State's rights. As will be seen later, this is an issue of special relevance where self-defence is exercised against a non-State actor within the territory of the host State.

\subsection{Effects of self-defence on victim-aggressor State relations}

The first step in understanding the function and scope of Article 21 is to separate the legal relations existing between the States involved in an armed conflict into three categories. First is the relation governed by the prohibition of force and its exception, the right of self-defence. Second are all the other legal relations (conventional or customary) existing between those States. These comprise an infinite variety ${ }^{44}$ and include the rights of territorial sovereignty and non-intervention, trade and commercial rights, treaties for the exchange of technology, and so on. Third is the category of legal relations which impose 'obligations of total restraint', ${ }^{45}$ including (some) rules of international humanitarian law and human rights law. As will be explained in what follows, the customary right of self-defence provides a legal ground of justification for the breach of the first and second sets of legal relations. These effects are codified in separate provisions: the legality of force under the first legal relation is addressed by Article 51, the legality of the impairment by (defensive) force of the second set of legal relations is addressed by Article $21 .^{46}$ The third set of legal relations cannot be impaired even when acting in self-defence.

\footnotetext{
44 The expression is taken from: R.R. Baxter, 'International Law in "Her Infinite Variety", (1980) 29 ICLQ 549.

45 ARS art 21 Commentary, at para. 4. The expression is the ICJ's: Legality of the Threat or Use of Nuclear Weapons, Advisory Opinion of 8 July 1996, [1996] ICJ Rep. 226, at 242, para. 30.

46 It may be worthwhile to recall that, as clarified by the ICJ in Nicaragua, Article 51 is not a complete statement of the law of self-defence as this exists in customary law. Customary law (to which a renvoi is made by Article 51's reference to the 'inherent right') complements the Charter provision. See: Nicaragua, at 94, para. 176.
} 


\subsubsection{First legal relation: On the legality of resort to force}

States are bound, under international law, by an obligation not to use force against one another. The prohibition, codified in Article 2(4) of the UN Charter, is widely regarded as one of jus cogens. ${ }^{47}$ This obligation not to use force possesses (at least) one exception in the form of a right of self-defence. ${ }^{48}$ What this means, essentially, is that States are bound to respect their obligation not to use force unless they are the victims of an armed attack, in which case they are authorized to respond to force with (defensive) force.

The structural relation between the prohibition of force and the right of selfdefence is very complex, and it has been conceptualized in many different ways. The ILC construed the prohibition of force and its exception of self-defence as a single norm. ${ }^{49}$ The prohibition of force and the right of self-defence, in other words, are two segments of an over-arching norm which can be restated, in simplified but relevant part, as follows: 'the use of force is prohibited except in self-defence against an armed attack'. In conceptualizing the norm in this way, the ILC was accommodating the opinions of States according to which the use of force in self-defence is not inconsistent with the prohibition of force and that it is, rather, lawful ab initio. ${ }^{50}$ In this understanding, the exception of self-defence constitutes a limit on the material scope of the prohibition. Thus, the prohibition of force would be applicable only if there were a non-defensive use of force and defensive force would fall wholly outside of the prohibition's scope of application. $^{51}$

47 For a thorough review of the relevant practice, see Corten, Droit contre la guerre, 341-59. A significant number of judges and scholars support the peremptory status of the prohibition of force: Nicaragua, sep op President Singh, at 153; sep op Judge Sette-Camara, at 199; Oil Platforms (Islamic Republic of Iran $v$ United States of America), Merits Judgment of 6 November 2003, [2003] ICJ Rep. 161, sep op Judge Kooijmans, at 260, para. 46; diss op Judge Elaraby, at 291; sep op Judge Simma, at 327, para. 6; Palestinian Wall, sep op Judge Elaraby, at 254; Ruys, Armed Attack, at 27; O. Dörr and A. Randelzhofer, 'Article 2(4)', in B. Simma et al (eds.), The Charter of the United Nations: A Commentary (2012) vol 1, 200 at 231; van Steenberghe, Légitime défense, at 137-40.

48 There are other exceptions too, see: S. Helmersen, 'The Prohibition of the Use of Force as Jus Cogens: Explaining Apparent Derogations', (2014) 61 NILR 167.

49 ARS art 21 Commentary, at para. 1. This reading was endorsed by Judge Tomka in: Case Concerning Armed Activities on the Territory of the Congo (DRC v Uganda), Merits Judgment of 19 December 2005, [2005] ICJ Rep. 168, Declaration Tomka, at 353-4.

50 See e.g., Ethiopia: UN Doc. A/C.6/35/SR.51, at 12, para. 46; Hungary: UN Doc. A/C.6/35/SR.55, at 12, para. 45; Mongolia: UN Doc. A/C.6/35/SR.53, at 8, paras. 29-30; Spain: UN Doc. A/C.6/35/SR.55, at 4, para. 11; Trinidad and Tobago: UN Doc. A/C.6/35/SR.56, at 6 para. 26; (then) USSR: A/C.6/35/SR.52, at 14, para. 63. On this point, see: Crawford, Second Report, 74-5.

$51 \quad$ Kammerhofer describes this approach as a 'gap' in the prohibition of force: J. Kammerhofer, Uncertainty in International Law: A Kelsenian Perspective (2011), at 9. 
The ILC's approach is, to be sure, not uncontested and has been criticised for its artificiality. ${ }^{52}$ Indeed, the relation between the two could be construed differently, in a way that upholds the autonomy of the right of self-defence from the prohibition of force. In this construction there would be two rules, the prohibition and the right, both applicable to the same set of facts: the use of defensive force would be banned under the prohibition of force and permitted by the right of self-defence. The two rules would, therefore, be in a normative conflict. To conclude in favour of the legality of self-defence, the right of self-defence must be able to set aside the application of the prohibition. This construction of the relation between the prohibition and the right runs into an obvious obstacle: the prohibition's peremptory status. As a jus cogens rule, the prohibition cannot be set aside, ${ }^{53}$ and the conflict would be resolved by the lex superior principle: the prohibition would prevail over the right, with the result that defensive force is unlawful. This is a paradoxical conclusion, in utter contradiction with the practice of States. The paradox can be overcome in one of two ways. First, by 'elevating', so to speak, the right of self-defence to a peremptory rule. In this case, the conflict would arise between two peremptory rules and could potentially be resolved by application of the lex specialis principle. ${ }^{54}$ Since self-defence is the most factually specific of the two rules, it would set aside the prohibition of force in the circumstances. Alternatively, it could be argued that only the prohibition of aggression possesses peremptory status. The resulting conflict between self-defence and the prohibition of force would be a conflict between 'ordinary' rules, in which self-defence would again prevail as the factually most specific rule. Both solutions, however, lack grounding in positive law: States do not accept the jus cogens status of the right of self-defence, ${ }^{55}$ and they do uphold the jus cogens status of the prohibition as a whole. ${ }^{56}$ The ILC's solution, artificial as it may be, appears to be the most descriptively accurate understanding of this relation. ${ }^{57}$

52 E.g. Fragmentation of International Law: Difficulties Arising from the Diversification and Expansion of International Law, Report of the Study Group of the International Law Commission, UN Doc A/CN.4/L.682, 13 April 2006, at 52-53, para. 95; J. Green, 'Questioning the Peremptory Status of the Prohibition of the Use of Force', (2011) 32 Mich J Int'l L 215; A. de Hoogh, 'Jus Cogens and the Use of Armed Force', in M. Weller (ed.), Oxford Handbook of the Use of Force in International Law (2015),1161 at $1172-$ 5.

53 As confirmed by ARS art 26: 'The wrongfulness of any act of a State which is not in conformity with an obligation arising under a peremptory norm of general international law.'

$54 \quad$ Assuming that conflicts between peremptory rules are resolved by reference to the principles of priority.

$55 \quad$ van Steenberghe, Légitime défense, 118.

56 See references supra, at note 47. It may be added that distinguishing 'aggression' from 'force' is not a simple task either in theory or in practice, on which see: C. Díaz Barrado, El consentimiento, causa de exclusión de la ilicitud del uso de la fuerza en derecho internacional (1989), 74-5.

57 See further, Paddeu, 'Self-Defence', at section II. 
In whatever way the relation is construed, the point is that the right of selfdefence constitutes an authorization to use force where force would otherwise be banned. To put it in symbolic terms, Article 51 of the Charter authorizes conduct otherwise prohibited by Article 2(4). When a State resorts to force in self-defence, Article 51 in a sense 'takes care' of the inconsistency existing between that force and Article 2(4): either by limiting the prohibition's scope or by setting aside its application in the circumstances. Crucially, however, the right of self-defence is not an authorization to impair all other rights of the aggressor State. ${ }^{58}$

\subsubsection{Second set of legal relations: 'Other' rights of the aggressor State}

The victim and aggressor States are also bound by an 'infinite variety' of other rights and obligations, be they customary or conventional. All of these other rights can potentially be impaired by military measures. The case-law of the ICJ and other international tribunals shows the great variety of rules of international law potentially impaired by the use of force: commercial obligations under bilateral treaties, ${ }^{59}$ aviation agreements, ${ }^{60}$ the obligation to settle disputes peacefully, ${ }^{61}$ and so on. Indeed, as the ICJ made clear in the Oil Platforms case, international obligations may be breached by whatever means: by the decision of a court, by an act of Parliament, or by the use of force. ${ }^{62}$

The question thus emerges whether the impairment of these obligations through defensive force is unlawful, or whether these impairments may be justified if the military force was resorted to in self-defence. Of course, it is perfectly plausible that these interferences are unlawful even if the State using force was acting in self-defence. As the

58 From the standpoint of Charter law, it could be argued that the language of art 51 does indeed authorize the impairment of other Charter-rights of the aggressor State. Thus, art 51 states that 'nothing in the present Charter shall impair...' Nevertheless, art 51 cannot authorize the impairment of customary rights. Art 103 of the Charter is not helpful in this regard. To begin with, it is limited to other conventional rights - though it seems logical that it may extend to customary rights as well. At any rate, art 103 gives priority to obligations arising under the Charter and not to rights.

59 See, eg, Nicaragua's claims at: Memorial of Nicaragua, Nicaragua, ICJ Pleadings, vol IV, 110-11, and oral statement, ICJ Pleadings, vol V, 210-12. For Iran's claims, see: Oil Platforms, at 166, para. 1; also at 176, para. 26.

60 See, eg, Memorial of Iran, Aerial Incident of 3 July 1988 (Iran v USA), at 146 (breach of the Chicago Convention), 182 (breach of the Treaty of Amity), 238 (both).

61 See, eg, Guyana v Suriname, Award, 17 September 2007, UNCLOS Annex VII Tribunal, at 147, para. 445, and dispositif at 165, para. 2, on the obligation to solve disputes peacefully contained in art 279 of the 1982 United Nations Convention on the Law of the Sea (UNCLOS), 1833 UNTS 397.

62 Oil Platforms (Islamic Republic of Iran $v$ United States of America), Preliminary Objection Judgment of 12 December 1996, [1996] ICJ Rep. 803, at 811-12, para. 21: 'The Treaty of 1955 imposes on each of the Parties various obligations on a variety of matters. Any action by one of the Parties that is incompatible with those obligations is unlawful, regardless of the means by which it is brought about. A violation of the rights of one party under the Treaty by means of the use of force is as unlawful as would be a violation by administrative decision or by any other means.' 
ICJ stated in Croatia v Serbia ' $[\mathrm{t}]$ here can be no doubt that, as a general rule, a particular act may be perfectly lawful under one body of legal rules and unlawful under another. ${ }^{63}$ Thus, self-defence may be lawful in relation to the prohibition of force and be unlawful in relation to, for example, the right of territorial sovereignty. Namely, a use of force may be compatible with the first legal relation mentioned above, but incompatible with the second set of legal relations.

Article 21 is concerned precisely with the justification of the collateral, so to speak, impairment of the aggressor State's rights caused by self-defensive force. The provision reflects a recurrent, if not directly acknowledged, phenomenon in practice. ${ }^{64}$ The ICJ, for example, has never directly acknowledged that self-defence may justify these collateral violations, though this effect can be deduced from its decisions in Nicaragua and DRC v Uganda. In Nicaragua the Court found that the violation of Nicaragua's territorial sovereignty and non-intervention by US military operations was not justified by selfdefence because, on the facts of the case, the US did not have a right of (collective) selfdefence. ${ }^{65}$ The same reasoning can be found in DRC $v$ Uganda, where the Court found that, since Uganda did not have a right of self-defence, its actions breached the DRC's rights of territorial sovereignty and non-intervention. ${ }^{66} A$ contrario, it may be inferred that if the US and Uganda had a right of self-defence against Nicaragua and the DRC respectively, then there would have been no breach of those rights either. In State practice, the parties' pleadings in Oil Platforms are especially instructive in this regard. On the question whether self-defence could justify the breach of the Iran-US 1955 Amity Treaty, ${ }^{67}$ the US, directly invoking Article 21 , maintained that '[a]ny actions of the US deemed incompatible with Article $\mathrm{X}$ of the Treaty would not be wrongful by the operation of this principle [self-defence] of customary international law. ${ }^{68}$ Iran also accepted this proposition, and said that:

63 Application of the Convention on the Prevention and Punishment of the Crime of Genocide (Croatia v Serbia) ICJ, Judgment of 3 February 2015, at para. 474. (not yet reported)

$64 \quad$ For additional examples in practice, see: Paddeu, 'Self-Defence'.

65 Nicaragua, at 126, paras. 247-9, on prohibition of intervention; 128, para. 251, on territorial sovereignty.

66 DRC v Uganda, at 227, para. 165, and 280, para. 345.1. Note that the Court only refers to the principle of non-use of force and the principle of non-intervention in the dispositif, even though the DRC had claimed also a breach of its territorial sovereignty and the Court had addressed it in its reasoning. For the DRC's prayer for relief, see: Memorial of the DRC, 273.

671957 Iran-US Treaty of Amity, Economic Relations and Consular Rights, 284 UNTS 93.

68 US Rejoinder, Oil Platforms, at 141, para. 5.02. The US's argument on this point changed throughout the pleadings, for a brief summary (in what concerns the point of art 21), see: Paddeu, 'SelfDefence' (forthcoming). 
[A]ction otherwise lawfully taken in self-defence could constitute a circumstance precluding wrongfulness in relation to Article X, paragraph 1, of the Treaty. In other words, it accepts the proposition contained in Article 21 of the ILC Articles on the Responsibility of States. ${ }^{69}$

Iran later added that if made out, self-defence would 'exonerate the United States entirely; it would provide a complete justification for their conduct, in accordance with Article 21 of the ILC's Articles. ${ }^{70}$

At customary law, then, it appears that self-defence can also justify the collateral impairment of these obligations by means of force. Article 21 simply reflects this additional function of the right of self-defence in the international legal order. It is worth pointing out that this is not an additional norm in the legal order, capable of going beyond the right of self-defence. Simply put, Article 51 and Article 21 codify different effects of the exercise of the customary right of self-defence in the legal order. Article 51 concerns its effect on the prohibition of force, and Article 21 the effects of that exercise on other legal relations.

\subsubsection{Third set of legal relations: Obligations of 'total restraint'}

Self-defence, however, cannot justify the collateral impairment brought about through force of all obligations of the victim State (or rights of the aggressor State). The Commentary to Article 21 expressly excludes from the scope of this provision what it termed, following the ICJ's advisory opinion in Nuclear Weapons, ${ }^{71}$ the 'obligations of total restraint'. ${ }^{72}$ By these are meant those obligations 'expressed or intended to apply as a definitive constraint even to States in armed conflict', including non-derogable human rights, the intransgressible ${ }^{73}$ principles of international humanitarian law and other obligations designed to place a limit on the conduct of hostilities. ${ }^{74}$ This exclusion was accepted by Iran in Oil Platforms, ${ }^{75}$ and by Uganda in DRC $v$ Uganda, whose memorial explicitly stated that self-defence may in no circumstances justify breaches of human rights and humanitarian law. ${ }^{76}$ Since the impairment of these obligations may not be justified by self-defence, no more will be said about them in this study.

\footnotetext{
69 Iran statement, Oil Platforms, CR 2003/5, at 41, para. 29. (references omitted)

$70 \quad$ Iran statement, Oil Platforms, CR 2003/7, at 51, para. 3.

Nuclear Weapons, at 242, para. 30.

ARS art 21 Commentary, at para. 4.

The term is, once again, taken from the ICJ's judgment in Nuclear Weapons, at 242, para. 30.

ARS art 21 Commentary, at para. 4.

Iran statement, Oil Platforms, CR 2003/5, at 41, para. 29. (references omitted)

Uganda Memorial, DRC v Uganda, at 232-3, paras. 5.93-94.
} 


\subsection{The effect of (defensive) force on third States?}

The Commentary to Article 21 specifies that the 'essential effect' of this provision 'is to preclude the wrongfulness of conduct of a State acting in self-defence vis-à-vis an attacking State. ${ }^{77}$ And yet, the use of force in international relations may, in addition, affect the rights of third (neutral) States. Can self-defence justify the impairment of these States' rights?

During the first reading of the ARS, the Commission had entirely foreclosed the possibility that self-defence may justify the impairment of third States' rights. The commentary to draft Article 34, the predecessor to Article 21, was clear in this regard:

The Commission [wished] to point out that the provision in article 34 is not intended to preclude the wrongfulness of, so to speak, indirect injury that might be suffered by a third State in connection with a measure of self-defence taken against a State which has committed an armed attack. ${ }^{78}$

The interests of third parties were, therefore, 'fully protected. ${ }^{79}$ But during the second reading of the ARS, the Commission changed its position. Prompted by Special Rapporteur Crawford, ${ }^{80}$ the ILC observed in 1999 that 'a State acting in self-defence might be entitled to take action against a third State' and that 'there was no need to make an explicit reference to that circumstance' in the text of, or Commentary to, Article 21 since the issue "was adequately covered by the relevant primary rules. ${ }^{81}$ To reflect this, the Commentary to Article 21 currently indicates that this provision 'leaves open all issues of the effect of action in self-defence vis-à-vis third States. ${ }^{82}$

\subsection{Interim conclusions}

A brief summary of the discussion so far may be useful before turning to the application of Article 21 to the exercise of self-defence against non-State actors. When a State resorts to force in self-defence, it does so against the background of the complex web of legal relations which bind it to the aggressor State (and third States). For analytical clarity, these legal relations were divided into three sets since the effect of the right of self-

\footnotetext{
$77 \quad$ ARS art 21 Commentary, at para. 5.

78 Commentary to art 34, ILC, Report of the Commission on the work of its thirty-second session, UN Doc. A/35/10 (1980), at 61, para. 28.

$79 \quad$ Ibid.

$80 \quad$ Crawford, Second Report, at 76, para. 302.

81 ILC, Report of the Commission on the work of its fifty-first session, UN Doc. A/54/10 (1999), at 77 , para. 321

$82 \quad$ ARS art 21 Commentary, at para. 5. 
defence on each of them is codified in different provisions. First is the prohibition of force. When force is resorted to in self-defence it does not constitute a breach of the prohibition since self-defensive force is excepted from the scope of the prohibition. In conventional law, the legality of the use of force is grounded on Article 51 of the UN Charter. Second, is the category of 'other' obligations of the victim State (or 'other' rights of the aggressor) which may be impaired by forcible measures including territorial sovereignty, non-intervention, commercial or other trade rights, and so on. The impairment of these obligations is also justified by self-defence: if the force that encroached upon them, in other words, constitutes a lawful exercise of the right of selfdefence in international relations. ${ }^{83}$ This justifying effect of self-defence, a sort of incidental effect of self-defence, is codified in Article 21 of the ARS. Third, is the category of legal relations which impose absolute restraints on States, even when acting in selfdefence, including non-derogable human rights and 'intransgressible' humanitarian law rules. The impairment of these obligations may not be justified, even by reference to the right of self-defence. Finally, Article 21 and its Commentary leave open the question whether the impairment of host State rights by self-defensive force may be justified.

\section{The circumstance precluding wrongfulness of self-defence and the use of force against non-State actors}

The ILC's work on Article 21 assumed the exercise of self-defence in an inter-State context. ${ }^{84}$ So long as self-defence is exercised as between two States-including when the armed attack is private but attributable to that State ${ }^{85}$-and the resort to force complies with the requirements of the jus ad bellum, then self-defence will also produce the incidental effect of justifying collateral violations of the aggressor State's rights. Could this provision be applied to situations involving unattributable armed attacks by nonState actors; namely, to situations where self-defence is exercised against a non-State

83 Art 21 requires compatibility both with the jus ad bellum and with the jus in bello, see Commentary, at para. 6. The discussion in this paper will only consider the issue from the standpoint of the jus ad bellum. ${ }_{84} \quad$ ARS art 21 Commentary, at para. 5.

85 Through whichever rule of attribution recognized in the ARS or, even, a lower standard of attribution recognized in the primary law, on which see: Crawford, General Part, at 158. See also C. Tams, 'The Use of Force against Terrorists', (2009) 20 EJIL 359 at 385-8; G. Nolte and A. Randelzhofer, 'Article 51', in B. Simma et al (eds.), The Charter of the United Nations: A Commentary (2012) vol 2, 1397 at 1416; Corten, Droit contre la guerre, at 717-58. See also van Steenberghe, cited above, for a review of relevant arguments. 
actor within the territory of the host State, so as to justify the impairment of host State rights by the defensive force? ${ }^{86}$

There is a crucial distinction between the 'essential' case covered by Article 21 and the present scenario, in that in the present scenario there is an additional party: the non-State actor. This additional party intrudes at the level of the first legal relation. The prohibition of force is, of course, owed as between the two States, the victim and the host State. Nevertheless, the exception of self-defence accommodates (or can accommodate) a third party: the non-State actor. The victim State is under an obligation not to resort to force unless it is the victim of an attack, which could include attacks by a private party. ${ }^{87}$ In positive terms, a State would be authorized to resort to force in international relations, whenever it is the victim of an armed attack-regardless of its source. This authorization is codified in Article 51 of the Charter which, in a sense, takes care of Article 2(4) whenever force is used in self-defence. Article 51 ensures that defensive force is not incompatible with the prohibition in Article 2(4), even if the defensive force is directed against a non-State actor. But this additional party is not accommodated by the second set of legal relations: these exist as between the victim State and the host State only. It is precisely for this reason that the 'dilemma' arises to begin with: while the victim may have a right of self-defence against the non-State actors, the defensive force encroaches upon the rights of a different entity, the host State.

Scholars have articulated different ways to resolve this dilemma. As noted in the Introduction, all these solutions have at their basis the (factual) premise of host State involvement with the private groups mounting the armed attack. The type and degree of involvement seems to be coalescing around a standard of 'unwillingness or inability', a standard which remains vague and has been abused. Be that as it may, of interest here is how the fact of State involvement (whatever the standard may be) has been and can be rationalized into a legal ground of justification that may explain why the host State's rights are not impaired by the use of defensive force in its territory. Section 3.1 will provide an overview and critique of the three main approaches offered by the scholarly literature to answer this question. Section 3.2 then considers whether Article 21 ARS may have a role to play in this regard.

\footnotetext{
$86 \quad$ On the distinction between self-defence against a State or within the State, see K. Trapp, 'Back to Basics: Necessity, Proportionality, and the Right of Self-Defence against non-State Terrorist Actors', (2007) 56 ICLQ 141 at 142; Lubell, Extraterritorial, at 36. For a contrary view, see: M.E. O'Connell, 'Dangerous Departures', (2013) 107 AJIL 380 at 383.

${ }_{87}$ This interpretation of Article 51 and the right of self-defence is accepted here for the sake of argument. As noted in the introduction, however, it is important to recall that whether this is accepted as a matter of customary law is debatable.
} 


\subsection{Insufficiency of the mainstream approaches}

Legal scholarship has appraised the fact of host State involvement with non-State actors in this context in at least three different ways: as an element of the requirement of necessity of self-defence, as a breach of international law by the host State through complicity with the non-State actors, and as a breach of a due diligence obligation to protect the rights of other States within its territory. ${ }^{88}$ None of these approaches has received generalized support in either State practice or the scholarly literature arguably because, as will be explained in what follows, each of these approaches is unsatisfactory in some way and this diminishes their explanatory power. ${ }^{89}$

According to some scholars, host State involvement with the non-State actors is relevant to the (customary) requirement of necessity of self-defence. ${ }^{90}$ Pursuant to this view, the right of self-defence of the victim State is triggered by the armed attack of the non-State actors and its exercise is limited by the conditions of necessity and proportionality. The host State's involvement with the non-State actor, so this view goes, would fall to be analysed under the requirement of necessity. Thus if the host State were willing and able to deal with the threat, then the use of force in self-defence would not be necessary. Contrariwise, if the host State is unwilling and/or unable to do so, then the necessity condition would be met and the victim State could lawfully resort to force against the non-State actors in the host State's territory.

This is a rather simple way to account for the host State's involvement with the non-State actors in situations of self-defence, but crucially it fails to explain why the impairment of host State rights caused by defensive force is justified. This can be elucidated by reference to the first two sets of legal relations described in Section 2. The requirement of necessity belongs to the first legal relation: the exceptional entitlement to use force in self-defence, codified in Article 51 of the Charter. The condition of necessity must be met to establish the legality of the resort to defensive force. When host State involvement is accounted for under the condition of necessity, it only serves to show that in the circumstances the victim State resorted to force against the source of the threat

$88 \quad$ Each of these approaches will be presented in its essential form, in a way which it is believed will be more or less acceptable to all scholars maintaining it. Of course, there may be variations in the details across the writings of various scholars, though these are immaterial to the point being made in this article.

89 Hakimi, 'Defensive Force against Non-State Actors', at 3-4.

90 Trapp, 'Back to Basics', at 146-147; van Steenberghe, 'A Step Forward?', at 199-202; Deeks, 'Unwilling or Unable', at 494-5; C. Tams and J. Devaney, 'Applying Necessity and Proportionality to AntiTerrorist Self-Defence', (2012) 45 Israel LR 91 at 98-101; D. Akande and T. Liefländer, 'Clarifying Necessity, Imminence, and Proportionality in the Law of Self-Defence', (2013) 107 AJIL 563 at 564-6. 
(the non-State actors) lawfully by reference to the norm prohibiting force in international relations. But the conclusion about the legality of the resort to force as such says nothing about the legality of the impairment of rules in the second set of legal relations (those between the victim and host State) affected by the exercise of self-defence-so precisely the ones the impairment of which is in need of legal justification. In addition, this solution distorts the 'original purpose', in Christine Gray's words, of the requirement of necessity: it treats necessity as an enabler of, rather than as a limitation on, the use of force. $^{91}$

Other scholars have rationalized host State involvement under the notion of complicity. On this view, since the host State is complicit in the armed attack of the nonState actor then it becomes liable to the use of defensive force against the non-State actor within its territory. ${ }^{92}$ This is not an argument about attribution-it is not the case, under this approach, that the complicity with the non-State actor determines the attribution of that armed attack to the host State. Rather, the position is that the host State's breach of its obligation not to aid or assist in the commission of a wrongful act by another renders it liable to the use of defensive force in its territory. This is a questionable conclusion. Under the law of State responsibility, complicity in the act of another State entails the responsibility of the accomplice. Crucially, the accomplice is responsible for its own conduct, for its own aid and assistance in the commission of a wrongful act by another State. ${ }^{93}$ In the current scenario, a host State would be responsible for assisting and aiding the non-State actors to engage in an armed attack. The host State's own wrongdoing (the aid and assistance) would entail its responsibility, in the form of cessation (if the act were continuing) and reparation towards the victim State. ${ }^{94}$ But the accomplice is not responsible for the wrongful act of the principal actor. The host State is thus not responsible for the private armed attack as such. ${ }^{95}$ This being the case, the host State is not liable, by the mere fact of its complicity with the non-State actors, to the use of force

$91 \quad$ C. Gray, 'The Limits of Force' (2016) 376 RCADI 93 at 111.

92 Eg R. Wolfrum and C.E. Philipp, 'The Status of the Taliban: Their Obligations and Rights under International Law', (2002) 6 Max Planck Ybk UN Law 559 at 594-5; R. Wolfrum, 'The Attacks of September 11, 2001, the Wars Against the Taliban and Iraq: Is There a need to Reconsider International Law on the Recourse to Force and the Rules in Armed Conflict?', (2003) 7 Max Planck Ybk UN Law 1 at 37-38; Ruys and Verhoeven, 'Attacks by Private Actors', at 315-17. For a summary and critique of this approach see: K. Trapp, State Responsibility for International Terrorism (2011), at 58-61.

93 ARS art 16 Commentary, at para. 10. In the literature, see: B. Graefrath, 'Complicity in the Law of International Responsibility', (1996) 29 RBDI 370 at 371 (complicity 'constitutes itself an internationally wrongful act of the State ... [i]t does not create a kind of co-responsibility in another State's responsibility ... [i]t has its own identity as a separate violation of international law').

94 See, generally, H. Aust, Complicity and the Law of State Responsibility (2011), at 269-86.

95 Becker, Terrorism and the State, at 224-5. 
in its territory. To be successful, this approach must explain why complicity in this context entails a consequence not normally entailed under the general law of responsibility. As it currently stands, however, the approach simply assumes this to be the case; the argument, that is, assumes the conclusion it seeks to prove.

The same criticism can be levelled at the third and final approach mentioned. Several scholars have attempted to ground the justification of the impairment of host State rights by defensive force by reference to the host State's infringement of its due diligence obligations. It is well-established that States have an obligation to protect the rights of other States within their own territory. ${ }^{96}$ When non-State actors operating in a State's territory successfully mount an armed attack against the victim State, the host State could be found to have breached its due diligence obligation. ${ }^{97}$ The infringement of this obligation, the argument goes, 'opens up' the State to force being used within its territory. ${ }^{98}$ As a result, the impairment of host State rights is lawful. But this too is an unconvincing argument. ${ }^{99}$ Just as with the argument based on complicity, the duediligence approach assumes the conclusion. A violation of due diligence obligations entails responsibility, including cessation and reparation; but this violation does not render the State liable to the use of force within its territory any more than the violation of any other rule (other than the prohibition of force) entails this consequence. ${ }^{100}$ The argument fails to explain why a breach of due diligence in the circumstances would generate this consequence. As it is, it too simply assumes this to be the case.

96 Corfu Channel (UK v Albania), Judgment of 15 December 1949, [1949] ICJ Rep. 4, at 22. See also, in the context of terrorism, General Assembly, Declaration on Principles of International Law concerning Friendly Relations and Co-operation among States in accordance with the Charter of the United Nations, A/RES/25/2625 (XXV) (24 October 1970). On this obligation see, generally, Trapp, State Responsibility for International Terrorism, at 64-82.

$97 \quad$ On due diligence obligations see: R. Pisillo Mazzeschi, 'The Due Diligence Rule and the Nature of the International Responsibility of States' (1992) 35 German YIL 5.

98 See, eg, D. Brown, 'Use of Force against Terrorism after September 11th: State Responsibility, Self-Defense and Other Responses', (2003) 11 Cardozo JICL 1, at 15, 30-32; T. Gazzini, The Changing Rules on the Use of Force in International Law (2005), at 189; Reinold, 'State Weakness, Irregular Warfare, and the Right of Self-Defense Post-9/11', at 284; Trapp, 'Can Non-State Actors Mount an Armed Attack?', in M. Weller (ed.), Oxford Handbook of the Use of Force in International Law (2015), 679 at 695; L. Moir, 'Action Against Host States of Terrorist Groups', in M. Weller (ed.), Oxford Handbook of the Use of Force in International Law (2015), 720 at 730. For a similar argument, see: R. Wedgwood, 'Responding to Terrorism: The Strikes against Bin Laden', (1999) 24 Yale JIL 559 at 565; B.A. Feinstein, 'A Paradigm for the Analysis of the Legality of the Use of Armed Force Against Terrorists and States that Aid and Abet Them', (2004) 17 Transnational Lawyer 51 at 77.

99 It is moreover problematic in that, by definition, a State's inability to deal with the non-State actor will not infringe its due diligence obligation. Due diligence obligations are obligations of means, not of result, and are premised upon the capacity of the State, in the circumstances, to engage in that conduct. See: F. Lozano Contreras, La noción de debida diligencia en derecho internacional público (2007), at 220-8.

$100 \quad$ Similarly: Ruys and Verhoeven, 'Attacks by Private Actors', at 317-318; Ruys, 'Thin Blue Line', 285; Antonopoulos, 'Force by Armed Groups', at 169-70. 
Both of the last two approaches, based on the notion of complicity and due diligence obligations, are underpinned to some extent by countermeasures-like reasoning. In essence, both approaches posit that one violation of international law (the complicity in another's wrongful act, or the breach of due diligence duties) justifies another violation of international law (the encroachment of host State rights). But countermeasures may not themselves involve the use of force, ${ }^{101}$ so it is not clear why the breach of obligations in these circumstances would attract a forcible response.

\subsection{Self-defence as a circumstance precluding wrongfulness: An alternative solution?}

None of the mainstream approaches provide a satisfactory explanation to the 'dilemma' of impairment of host State rights by the use of defensive force against non-State actors within that State's territory. Could Article 21 provide an alternative solution?

The scenario where a State exercises self-defence against a non-State actor in another State's territory is not the 'essential' situation falling within the ambit of Article 21 - that of inter-State self-defence-as noted earlier. Rather, the situation of the host State is better assimilated to one involving a third party affected by the exercise of selfdefence. The action in self-defence exists as between the victim State and the non-State actor, and the host State is an (affected) third State. As was mentioned in Section 2.2, the ILC does not answer the question whether Article 21 can justify the impairment of third State rights by an action in self-defence. The matter, it says, is left 'open'. In this way, the ILC does not foreclose the possibility that Article 21 may extend to the justification of the impairment of third party rights. Insofar as Article 21 codifies an effect of the right of self-defence at customary law, ${ }^{102}$ the question then is whether as a matter of customary law the exercise of self-defence permits these intrusions on third parties' rights.

There are two relevant bodies of law relevant to this question. First, the law of neutrality which protects the rights of, and imposes duties on, third parties during armed conflict. A third party may, by its involvement with one of the parties in conflict, forfeit its neutral protection and render itself liable to attack by the opposing party. Where this is the case, there is no role for Article 21 to play: the law of neutrality would itself resolve the 'dilemma' of host State rights. Second, is the right of self-defence itself. In certain

\footnotetext{
$101 \quad$ ARS art 50(1)(a).

102 Recall that art 51 of the Charter and art 21 of the ARS reflect different effects of the customary right of self-defence: art 51 concerns the effect of self-defence on the prohibition of force, art 21 its effect on the second set of legal relations.
} 
circumstances - whether or not a third State is involved in any way in the conflict-a self-defending State may lawfully impair (some of) the third States' rights. Does this extend to the impairment of any of its rights? If so, such an effect could be rationalized under Article 21 of the ARS.

\subsubsection{What role for the law of neutrality?}

Under the law of neutrality, neutral States have a right not to be affected by the conflict and they have duties of non-participation and impartiality. ${ }^{103} \mathrm{~A}$ neutral State which renders assistance to one of the parties to an armed conflict thereby violates its neutral duties, and becomes liable to reprisals by the affected belligerent. Nevertheless, this is not a liability to forcible reprisals. Since international law prohibits armed reprisals, ${ }^{104}$ the affected belligerent may not use force against the neutral State on this ground. According to Michael Bothe, the only circumstances in which the neutral State may be liable to forcible attack by the affected belligerent is when its violation of neutral duties amounts to an armed attack: 'a reaction against violations of neutrality which would involve the use of force against another State is permissible only where the violation of the law triggering that reaction itself constitutes an illegal armed attack. ${ }^{105}$ The standard is high: not all support for an aggressor is equivalent to an armed attack. ${ }^{106}$ Bothe notes that the non-neutral services rendered by the US, Saudi Arabia and Kuwait to Iraq, for example, 'did not entitle Iran to adopt measures against those states involving the use of military force. ${ }^{107}$ Applying this to the present context, ${ }^{108}$ the use of force would be permissible within the host State's territory whenever its assistance to the non-State actors amounts to an armed attack.

The difficulty is, of course, that of determining when assistance amounts to an armed attack: is attribution necessary, or will an indirect attack suffice? By requiring a degree of State involvement with the non-State actors (or any other State in conflict) amounting to 'an armed attack' against the other party, the law of neutrality reaches the

\footnotetext{
103 M. Bothe, 'The Law of Neutrality', in D. Fleck (ed.), Handbook of International Humanitarian Law (3rd edn, 2013), at 549.

$104 \quad$ ARS art 50(1)(a).

105 Bothe, 'Neutrality', at 558.

106 Id.

$107 \quad$ Ibid, at fn. 39.

108 Note that the applicability of the law of neutrality to conflicts between States and non-State actors is contested. See, eg, the exchange between K. Chang, 'Enemy Status and Military Detention in the War Against Al-Qaeda', (2011) 47 Texas ILJ 1; R. Ingber, 'Untangling Belligerency from Neutrality in the Conflict with Al-Qaeda', (2011) 47 Texas ILJ 76; K.J. Heller, 'The Law of Neutrality does not Apply in the Conflict with Al-Qaeda, and it is a Good Thing too: A Response to Chang', (2011) 47 Texas ILJ 115.
} 
same stalemate as any arguments based on Article 51: failing attribution of the non-State actors' conduct to the host State, there will be no entitlement for the victim to use force against, or even within, the host State. A plausible avenue for development could be the lowering of the threshold of host State involvement with the non-State actors, such that, for example, unwillingness and inability to deal with the private groups might suffice. But there are two weaknesses in this argument. First, it is difficult to see how unwillingness and, especially, inability might constitute an involvement equivalent to an armed attack. Second, it would probably be simpler to redefine the notion as a matter of the right of self-defence itself. At any rate, given the reluctance to redefine the notion of armed attack in the context of the right of self-defence, it is highly unlikely that the law of neutrality might develop in this direction.

\subsubsection{Self-defence and third parties}

The other possibility is that the right of self-defence itself may allow a State to use of force against third parties or, more likely, that it permits the impairment of third party rights by self-defensive force. Certain impairment of third-State rights during hostilities have been justified on the grounds of a State's exercise of self-defence. This is the case, for example, of the institution of war-zones or maritime exclusion zones on the high seas, where they affect the freedom of navigation of all States. ${ }^{109}$ While in the past these would have been grounded on the exercise of belligerent rights, in recent decades recourse to self-defence as a legal basis of justification for these interferences is increasing. ${ }^{110}$

States having justified interferences with neutral shipping on the basis of selfdefence include France, during the Algerian emergency of the mid 1950s, and Pakistan, during the Indo-Pakistani conflict of $1965 .{ }^{111}$ The UK justified the institution of a 200 nautical miles exclusion zone around the Falkland/Malvinas and the institution of 'security bubbles' around its warships traveling through the Atlantic Ocean on the right of self-defence. ${ }^{112}$ These zones were initially applied only against Argentine warships, though they were later extended to 'any other ship, whether naval or merchant vessel,

\footnotetext{
109 C. Michaelsen, 'Maritime Exclusion Zones in Times of Armed Conflict at Sea: Legal Controversies Still Unresolved', (2003) 8 J Conflict Security Law 363 at 388.

110 N. Klein, Maritime Security and the Law of the Sea (2011), at 275.

111 D. Humphrey, 'Belligerent Interdiction of Neutral Shipping in International Armed Conflict', (1997) 2 J Conflict \& Security Law 23 at 29.

112 See, eg, Debate on the subject of the Falkland Islands, in (1982) 53 BYIL 540 (statement by Margaret Thatcher); and the various letters to the President of the UN Security Council in (1982) 53 BYIL 539-549.
} 
which $\ldots$ is operating in support of Argentina. ${ }^{113}$ Note, however, that in practice interference with neutral shipping in these circumstances has been rather limited. ${ }^{114}$ During the Iran-Iraq war at least two States, the $\mathrm{UK}^{115}$ and the US, ${ }^{116}$ accepted the principle that self-defence could justify interference with neutral shipping when there was reasonable suspicion of non-neutral service. ${ }^{117}$ In particular, the UK held that:

a State ... actively engaged in an armed conflict, is entitled in exercise of its inherent right of self-defence to stop and search a foreign merchant ship on the high seas if there are reasonable grounds for suspecting that the ship is taking arms to the other side for use in the conflict. ${ }^{118}$

On the whole, the Iraqi and Iranian war-zones were widely criticized by other States and by the Security Council. But as emphasized by Ross Leckow, these critiques responded to the 'little respect ... shown by either side for [the] principle of restraint' in their enforcement of these areas. It was 'because of this complete disregard for "reasonableness" that attacks on neutral merchant vessels on both sides must be condemned as violations of international law. ${ }^{119}$ Most recently, after the 9/11 attacks, the US engaged in the boarding of neutral vessels suspected of transporting terrorists. While the explicit legal basis for this was never articulated, the US generally justified its action in this regard on the right of self-defence. ${ }^{120}$ As this practice shows, interference with neutral shipping is permitted when there is a suspicion of collaboration between the third State and the aggressor.

The legal basis of interference with neutral shipping, to be sure, remains a matter of some debate: some uphold a wider right of interference as a matter of belligerent rights, and therefore available to both victim and aggressor State, whereas others-like the examples just mentioned-opt for a narrower right based on a State's exercise of self-defence. ${ }^{121}$ As observed by Natalie Klein, the invocations of self-defence are of

\footnotetext{
113 British letter, 9 April 1982, addressed to the President of the UN Security Council in (1982) 53 BYIL 539.

114 R. Leckow, 'The Iran-Iraq Conflict in the Gulf - The Law of War Zones', (1988) 37 ICLQ 629 at 634.

115 For the UK's position, see: C. Gray, 'The British Position in Regard to the Gulf Conflict', (1988) 47 ICLQ 420.

116 The US subsequently asserted a different position, and it may be wondered if this was in response to the indiscriminate policy followed by Iran and Iraq in the enforcement of these rights. On the evolution of the US position, see: Humphrey, 'Belligerent Interdiction', at 33-4.

117 Humphrey, 'Belligerent Interdiction', at 32-3.

118 Quoted by Gray, 'British Position', at 423.

119 Leckow, 'Iran-Iraq Conflict', at 644.

120 On which see: Klein, Maritime Security, at 274.

121 P. Wendel, State Responsibility for Interferences with the Freedom of Navigation in Public International Law (2007), at 233-6.
} 
special significance given their context. In her view, '[t]his recent practice should be seen against previous practice where there was far less acceptance of reliance on the right of self-defence to justify intrusions against the freedom of navigation on the high seas. ${ }^{122}$ This practice, at the very least, shows States' willingness accept the impairment of the rights of third States in the exercise of self-defence in certain, if limited, circumstances.

The reasoning underpinning the legal justification of these interferences with third party rights could be extended, by analogy, to the 'dilemma' of host State rights as well. The analogy could be built on the UK's position on self-defence-based interferences with neutral shipping, quoted earlier, as this is the clearest articulation of a justification for impairment of third State rights. Under the UK position, a State acting in self-defence may impair the rights of third States to freedom of navigation only where there is suspicion of involvement between the third State and the aggressor. Involvement, in this regard, amounts to assistance in the form of arms-provision-so a far lower standard than what is necessary for that assistance to itself constitute an armed attack. Applying this same reasoning to the non-State actor scenario, the victim State exercises its right of self-defence against the non-State actor and, in so doing, it impairs the rights of a third party, the host State. Such interference may justified under self-defence so long as there exists some measure of host State involvement with the non-State actor, an involvement which need not amount to an armed attack and could, if accepted, be as limited as unwillingness and inability. Nevertheless, given the different extent to which third State rights are impaired in the two scenarios (in one case, the right of freedom of navigation, in the other, the rights to territorial sovereignty, non-intervention, and so on), it may be necessary to qualify the UK position above if it is to apply in respect of hostStates: rather than a reasonable suspicion of host State involvement, host State involvement must actually exist and must, therefore, be proven.

To put this approach in terms of Articles 51 of the Charter and 21 of the ARS, the resort to force in self-defence against the aggressor (the non-State actor) would be grounded on Article 51 of the Charter-which, it may be recalled, is applicable only to the question of the legality of the use of force by reference to the general prohibitionwhereas the interference with third State rights may be grounded on Article 21 ARS. ${ }^{123}$ Such an approach, which relies on Article 21 in addition to Article 51, overcomes the

\footnotetext{
$122 \quad$ Klein, Maritime Security, at 275.

123 For a similar view, see: R. O'Keefe, 'War and the Law of Nations: A General History. By Stephen C Neff [Cambridge: Cambridge University Press. 2005. xii. 398 and (Biibliography, Table of Cases, Table of Treaties, Index, 44 pp. Hardback f,55.00. ISBN 0-521-66205-2.]', (2007) 66 CLJ 461 at 462.
} 
explanatory difficulties of the mainstream theories reviewed earlier. To begin with, it relies on the concept of 'circumstances precluding wrongfulness', a category of rules of the law of responsibility whose function is precisely that of justifying the infringement of legal rules. Moreover, the relevant circumstance precluding wrongfulness, Article 21, can justify the breach of obligations brought about through the use of force, which no other circumstance precluding wrongfulness can do. ${ }^{124}$

\section{Conclusion}

The use of force against non-State actors presents, for international law, a clear dilemma: it is not possible to expect the victim of non-State actors' assaults to tolerate that conduct, but by the same token the rights of the host State must be upheld. State practice, albeit far from the generality, uniformity and consistency necessary for the modification of customary law, shows an increased acceptance of a right of self-defence against non-State actors-but the recognition of this right must overcome an important difficulty: how legally to justify the interference with the rights of the host State by the use of force in its territory?

Scholars working in this field have proposed different explanations for the justification of interferences with host State's rights. Building from the practice of States, they all rely, in some form or another, on the involvement of the host State with the nonState actors. Nevertheless, they disagree as to the rationalization of the fact of involvement into a ground of legal justification. Thus, some scholars view host State involvement as relevant to the condition of necessity of self-defence, others as a form of complicity, and others still as a breach of the host State's due diligence obligation to protect the rights of the victim State in its territory. But none of these approaches is sufficient: at the crucial point, that of explaining why the host State is liable to the use of force within its territory, they all contain leaps in the reasoning.

This study has proposed an alternative answer to this question, one based on Article 21 of the ARS, namely on self-defence in its role as a circumstance precluding wrongfulness. This provision, albeit much misunderstood in the literature, has an important role to play in inter-State invocations of self-defence. It is Article 21 which explains why force that is lawful under Article 51 of the Charter does not constitute an infringement of other rights of the target State, most importantly of its right of territorial

$124 \quad$ For an overview, see Corten, Droit contre la guerre, at ch 4. 
sovereignty. While Article 21 assumes an inter-State use of force, in which there is identity of the parties to the relevant legal relations (self-defence, territorial sovereignty, and so on), its Commentary shows that Article 21 may extend to the justification of the interference with the rights of third States, namely situations in which there is a mismatch between the parties to the relevant legal relations. Indeed, the right of self-defence may, in certain circumstances, impair the rights of third parties. Thus, States have justified the institution of maritime exclusion zones, affecting third party rights of free navigation, on the basis of self-defence. Perhaps host State involvement with the non-State actors may be reconceptualized as one of the situations in which the right of self-defence permits interference with a third party, the host State. This way, the legal relation between the victim State and the non-State actor would be governed by Article 51, and the legal relations between the victim State and the host State would be governed, and thereby justified, by Article 21.

To be sure, a solution based on Article 21 is still far from being entirely satisfactory. This is not so much as a result of the approach itself, but of the difficulties inherent in the claim that force can be lawfully used in self-defence against non-State actors. These difficulties are both legal and practical. Legally, any theory about the use of self-defence against non-State actors must overcome an important hurdle: that of grounding the illegality of the armed attack. An armed attack, to trigger the right of selfdefence, must not be merely a 'factual' armed attack: ${ }^{125}$ it is necessary that it also be unlawful. If this were not the case, then the continued validity of the principle 'no selfdefence against self-defence ${ }^{, 126}$ would be undercut. For if all that is necessary is a factual armed attack, regardless of its legal qualification, then a use of force in self-defence can, too, be a factual armed attack (if it attains the required gravity threshold) triggering the aggressor's own right of self-defence. The result is a logical spiral of violence, where selfdefence can be invoked against self-defence. Yet, there is no identifiable ban on the use of force by non-State actors. ${ }^{127}$ Practically, the desirability of this development remains

\footnotetext{
125 On which see, eg, Ruys, Armed Attack, at 490 (arguing that Article 51 neither prohibits armed attacks nor points to their illegality).

126 Ministries trial, 329; The Maria, 361. See also, Lubell, Extraterritorial, at 41; Dinstein, War, Aggression and Self-Defence, at 190.

127 Kammerhofer, Uncertainty, at 40; A. de Hoogh, 'Restrictivist Reasoning on the Ratione Personae Dimension of Armed Attacks in the Post 9/11 World' (2016) 29 LJIL 19, at 22. But see van Steenberghe, Légitime defense, at 289-90. For a proposal in this regard, see: A.M. Slaughter and W. Burke-White, 'An International Constitutional Moment', (2002) 43 HILJ 1, at 2.
} 
questionable, as recently shown by Christine Gray, who has argued that the use of force against non-State actors is far from an effective instrument. ${ }^{128}$

Article 21 can provide a sound framework to address the 'dilemma' of host State rights. This solution still requires, however, acceptance as a matter of positive law, through the practice of States and their opinio juris. But the availability of the right of selfdefence against non-State actors still has many hurdles to overcome.

128 Gray, 'The Limits of Force', 93-197. 